\title{
Mesquite seed gum and Nile tilapia fish gelatin composite films with cellulose nanocrystals
}

\author{
Mabel Ribeiro da Cruz ${ }^{(1)}$, João Paulo Saraiva Morais ${ }^{(2)}$, Celli Rodrigues Muniz ${ }^{(3)}$, Morsyleide de Freitas Rosa( ${ }^{(3)}$, \\ Men de Sá Moreira de Souza Filho ${ }^{(3)}$ and Henriette Monteiro Cordeiro de Azeredo ${ }^{(3,4)}$
}

${ }^{(1)}$ Universidade Federal do Ceará, Departamento de Engenharia Química, Campus do Pici, Bloco 709, CEP 60455-760 Fortaleza, CE,
Brazil. E-mail: mabelribeirodacruz@yahoo.com.br ${ }^{(2)}$ Embrapa Algodão, Rua Oswaldo Cruz, no 1.143, Centenário, CEP 58428-095 Campina
Grande, PB, Brazil. E-mail: joao.morais@embrapa.br ${ }^{(3)}$ Embrapa Agroindústria Tropical, Rua Dra. Sara Mesquita, no 2.270 , Planalto do
Pici, CEP 60511-110 Fortaleza, CE, Brazil. E-mail: celli.muniz@embrapa.br, morsyleide.rosa@embrapa.br, men.souza@embrapa.br,
henriette.azeredo@embrapa.br ${ }^{(4)}$ Embrapa Instrumentação, Rua XV de Novembro, № 1.452, Centro, CEP 13560-970 São Carlos, SP, Brazil.

Abstract - The objective of this work was to determine a suitable combination of the polysaccharide mesquite seed gum (MSG) and the protein Nile tilapia fish gelatin in the composite MSG/gelatin film for food packaging applications, and to evaluate the effect of cellulose nanocrystals (CNCs) on the film. MSG and gelatin were extracted from mesquite seeds and Nile tilapia residues, respectively, and the CNCs from mesquite pods by acid hydrolysis. The MSG:gelatin ratio with the best combination of tensile and barrier properties was used to produce the bionanocomposite films, by adding different $\mathrm{CNC}$ contents to the MSG/gelatin dispersion. The MSG:gelatin ratio of 1:1 had a good combination of water vapor permeability (WVP) and tensile strength. The properties of the MSG/gelatin films were improved by the CNCs, mainly at $5 \mathrm{wt} \%$, which produced the highest tensile strength and modulus, more than 30\% higher than those of the control film, and the lowest WVP, $23 \%$ lower than that of the control. Higher $\mathrm{CNC}$ contents resulted in the aggregation of nanocrystals, impairing barrier and tensile properties. The nanocomposite film with MSG, gelatin, and CNCs at the respective weight ratios of 1:1:0.1 presents the best overall properties for food packaging applications.

Index terms: Prosopis juliflora, bionanocomposites, packaging, polysaccharide, protein.

\section{Filmes compósitos de galactomanana de algaroba e gelatina de tilápia-do-nilo com nanocristais de celulose}

Resumo - O objetivo deste trabalho foi determinar uma combinação adequada entre o polissacarídeo galactomanana de algaroba e a proteína gelatina de tilápia-do-nilo no filme compósito galactomanana/ gelatina para aplicações em embalagem de alimentos, e avaliar a influência de nanocristais de celulose (NCC) sobre o filme. A galactomanana e a gelatina foram extraídas de sementes de algaroba e resíduos de tilápia-do-nilo, respectivamente, e os NCC de vagens de algaroba, por hidrólise ácida. A proporção galactomanana:gelatina com a melhor combinação de propriedades mecânicas e de barreira foi usada para produzir filmes bionanocompósitos, pela adição de diferentes teores de NCC à dispersão de galactomanana/ gelatina. A proporção galactomanana:gelatina de 1:1 apresentou boa combinação entre permeabilidade a vapor de água $\left(\mathrm{P}_{\mathrm{VA}}\right)$ e resistência mecânica. As propriedades dos filmes foram melhoradas pela adição de NCC, principalmente a $5 \%(\mathrm{~m} / \mathrm{m})$, que produziu os máximos valores de resistência e módulo, com mais de $30 \%$ de aumento em relação ao filme controle, e os menores valores de $\mathrm{P}_{\mathrm{VA}}, 23 \%$ a menos que o controle. Maiores teores de NCC resultaram em agregação dos nanocristais e prejudicaram as propriedades de barreira e mecânicas. O filme nanocompósito com galactomanana, gelatina e NCC nas respectivas proporções de 1:1:0,1 apresentam as melhores propriedades gerais para aplicações em embalagem de alimentos.

Termos para indexação: Prosopis juliflora, bionanocompósitos, embalagem, polissacarídeo, proteína.

\section{Introduction}

The mesquite tree [Prosopis juliflora (Sw.) DC.] is a fast growing species tolerant to water scarcity and saline soils, well adapted to the semiarid zones of Brazil's Northeast, where it is highly widespread.
Its seeds produce mesquite seed gum (MSG), a galactomannan with a galactose:mannose ratio of 1:1.1 (Vieira et al., 2007).

The climatic conditions and abundance of freshwater in Brazil are ideal for the aquaculture of Nile tilapia 
(Oreochromis niloticus), whose production is expected to surpass 490,000 tons by 2020 (Fontes et al., 2016). Nile tilapia is usually processed into fillets, leaving skin, bones, and scales as important residues from the fishing industry, from which gelatin may be obtained by partial hydrolysis of the collagen present in the residues. Although the most usual gelatin sources are animal bones and skin generated as wastes from bovine and porcine meat processing, alternative sources have been increasingly demanded, due to the outbreak of bovine spongiform encephalopathy, as well as to religious considerations (Chiou et al., 2009). Gelatins from fish wastes have been considered interesting alternatives, especially those from warm water fishes such as Nile tilapia, which have higher proline and hydroxyproline contents, and, therefore, better tensile and thermal properties when compared with cold water species (Chiou et al., 2009).

Some studies have been based on the development of films from combinations between polysaccharides and proteins (Guerrero et al., 2013; Leuangsukrerk et al., 2014; Li et al., 2015), but the combination galactomannan/gelatin has only been suggested for tissue engineering applications (Siqueira et al., 2015), with no reinforcing agents. The addition of reinforcing nanostructures, such as cellulose nanocrystals (CNCs), has been proved effective to improve tensile and barrier properties of biopolymer films (Siqueira et al., 2010; Bras et al., 2011), due to the formation of a continuous and rigid network governed by a percolation mechanism (Bras et al., 2011). Moreover, CNCs may reduce film permeability to water vapor, which is mainly attributed to the increased tortuosity of the path to water vapor by the presence of impermeable CNCs distributed in the matrix (Abdollahi et al., 2013).

The objective of this work was to determine a suitable combination of the polysaccharide MSG and the protein Nile tilapia fish gelatin in the composite MSG/gelatin film for food packaging applications, and to evaluate the effect of $\mathrm{CNCs}$ on the film.

\section{Materials and Methods}

The experiment was carried out at Embrapa Agroindústria Tropical, located in Fortaleza, in the state of Ceará, Brazil. For the extraction of MSG, mesquite seeds were manually separated from pods and fibers, dried at $55^{\circ} \mathrm{C}$ for 24 hours in the
SL-102 oven (Solab: Equipamentos para Laboratórios, Piracicaba, SP, Brazil), dehulled, and ground to a 30-mesh powder in a Wiley mill. The mesquite seed powder was immersed in distilled water (powder per water ratio of $1: 6 \mathrm{~g} \mathrm{~mL}^{-1}$ ) under stirring at $150 \mathrm{rpm}$ for 1 hour at $50^{\circ} \mathrm{C}$, then filtered. The viscous filtrate was centrifuged at $24,600 \mathrm{~g}$ for $30 \mathrm{~min}$ at $20^{\circ} \mathrm{C}$, precipitated with ethanol $92.8 \%$ (filtrate per ethanol ratio of $1: 2, \mathrm{v} / \mathrm{v}$, for 24 hours at $4{ }^{\circ} \mathrm{C}$ ), and centrifuged again at $24,600 \mathrm{~g}$ for $30 \mathrm{~min}$ at $20^{\circ} \mathrm{C}$. The resulting precipitate (MSG) was dried at $40^{\circ} \mathrm{C}$ for 48 hours also in the SL-102 oven and milled to a powder using the A11 basic mill (IkaWerke GmbH \& Co. KG, Staufen, Germany).

A gelatin powder was obtained as described in a previous study (Santos et al., 2014), with some modifications. The Nile tilapia residue (skins, bones, and scales) was thoroughly washed, immersed in a $0.2-$ $\mathrm{N}$ acetic acid solution (1:2 residue per solution weight) for $60 \mathrm{~min}$, neutralized in $1 \mathrm{~mol} \mathrm{~L}^{-1} \mathrm{NaOH}$, filtered, then subjected to acid hydrolysis in $\mathrm{H}_{2} \mathrm{SO}_{4} 0.2$ mol L-1 solution and alkaline hydrolysis in $\mathrm{NaOH} 0.2 \mathrm{~mol} \mathrm{~L}^{-1}$ solution, both followed by neutralization and filtration. The hydrolyses were carried out at a residue per solution ratio of $1: 3 \mathrm{~g} \mathrm{~mL}^{-1}$ under stirring for $60 \mathrm{~min}$. The neutralized residue was then immersed in distilled water for 2 hours at $50^{\circ} \mathrm{C}\left(1: 5 \mathrm{~g} \mathrm{~mL}^{-1}\right.$ residue per water ratio) under stirring, vacuum filtered through $28-\mu \mathrm{m}$ filter paper, freeze dried, and ground with the A11 basic analytical mill (Ika-Werke $\mathrm{GmbH} \& \mathrm{Co}$. KG, Staufen, Germany).

The CNCs were obtained from mesquite pods by acid hydrolysis (Morais et al., 2013) with aqueous sulfuric acid $(60 \%, \mathrm{v} / \mathrm{v})$ at a 1:20 (w/v) pods:acid solution ratio under stirring for 1 hour at $50^{\circ} \mathrm{C}$. The reaction was stopped by the addition of cold deionized water $\left(4^{\circ} \mathrm{C}\right)$ at a suspension per water ratio of $1: 10(\mathrm{v} / \mathrm{v})$; then, the suspension was subjected to three cycles of centrifugation $\left(18,894.2 \mathrm{~g}\right.$ for $15 \mathrm{~min}$ at $\left.20^{\circ} \mathrm{C}\right)$, re-suspension in deionized water $(1: 10, \mathrm{v} / \mathrm{v})$, and sonication using the DES500 ultrasonic cell disruptor (Unique Group, Indaiatuba, SP, Brazil) at a constant frequency of $60 \mathrm{kHz}$ for $4 \mathrm{~min}$ at $100 \mathrm{~W}$. After those three cycles, the $\mathrm{CNC}$ suspension was dialyzed against deionized water with two daily changes of water until a $\mathrm{pH}$ of 7 was reached. The solid content of the dialyzed CNC suspension was determined by gravimetry after drying at $105^{\circ} \mathrm{C}$ in a drying oven until constant weight. The zeta potential of the CNCs was measured in 
triplicate using the Zetasizer Nano ZS 3000 analyzer (Malvern Instruments Ltd., Worcestershire, UK) for $\mathrm{CNC}$ suspensions diluted to $0.1 \mathrm{wt} \%$ with deionized water. $\mathrm{CNC}$ dimensions were measured by atomic force microscopy (AFM) in the Multimode AFM microscope (Veeco Instruments, Santa Barbara, CA, USA) equipped with the Nanoscope software, version 7.30 (Bruker Corporation, Santa Barbara, CA, USA), using a silicon nitride cantilever with a 80 $100-\mathrm{nm}$ radius tip, at a spring constant of $0.15 \mathrm{~N} \mathrm{~m}^{-1}$ and a resonance frequency of $1 \mathrm{kHz}$. Dilutions were made with Milli-Q water to a CNC concentration of $0.5 \mathrm{~g} \mathrm{~L}^{-1}$. The suspensions were placed to dry on a muscovite mica basal plane surface. The dimensions were measured using the WSxM 5.0 Develop software, version 6.5 (Horcas et al., 2007).

The MSG dispersion was prepared by diluting $6 \mathrm{~g}$ MSG in $100 \mathrm{~mL}$ distilled water under magnetic stirring at $25^{\circ} \mathrm{C}$ for $60 \mathrm{~min}$, then at $45^{\circ} \mathrm{C}$ for another $60 \mathrm{~min}$. A gelatin dispersion was prepared by diluting $9 \mathrm{~g}$ gelatin in $100 \mathrm{~mL}$ distilled water under magnetic stirring at $25^{\circ} \mathrm{C}$ for $60 \mathrm{~min}$, then at $40^{\circ} \mathrm{C}$ for another $30 \mathrm{~min}$. Five film forming dispersions were prepared by mixing both one-component dispersions in order to obtain the following MSG per gelatin dry weight ratios: $0: 1,1: 3,1: 1,3: 1$, and 1:0, determined according to a simplex-centroid design. The dispersions were added with glycerol ( $25 \%$ on a dry basis), homogenized with the Ultra Turrax T-25 disperser (Ika-Werke GmbH \& Co. KG, Staufen, Germany) at $15,000 \mathrm{rpm}$ for 15 min, degassed with the V-700 vacuum pump (Büchi Labortechnik AG, Flawil, Switzerland) at 30 mbar for $30 \mathrm{~min}$, cast on $0.3 \times 0.3-\mathrm{m}$ Mylar substrate on glass plates, leveled with a draw-down bar for a final thickness of $0.07 \mathrm{~mm}$, and dried at $35^{\circ} \mathrm{C}$ for 24 hours in the SL-102 oven (Solab: Equipamentos para Laboratórios, Piracicaba, SP, Brazil). Dried samples were cut and detached from the surface. Before film characterization, the free-standing samples were conditioned for at least 24 hours at $25^{\circ} \mathrm{C}$ in desiccators containing a saturated solution of calcium nitrate tetrahydrate, in order to maintain a constant relative humidity around $48 \%$.

The tensile properties of $80 \times 10$-mm film strips were measured in five replicates according to the D882-10 standard test method (ASTM, 2010a), using the DL3000 universal testing machine (Emic: Equipamentos e Sistemas de Ensaio, Ltda., São José dos Pinhais, PR,
Brazil) with a load cell of $100 \mathrm{~N}$, initial grip separation

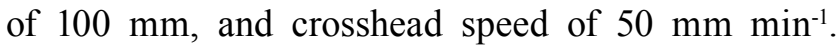
Water vapor permeability (WVP) was determined in eight replicates, based on the E96-10 method (ASTM, 2010b), at $25^{\circ} \mathrm{C}$, using silica gel at $0 \%$ relative humidity $(\mathrm{RH})$ and water at $100 \% \mathrm{RH}$ as desiccants outside and inside the permeation cells, respectively. At least seven measurements were taken within 24 hours. Opacity was obtained in triplicate, based on the method described by Irissin-Mangata et al. (2001). Films were cut into rectangular $1 \times 5-\mathrm{cm}$ strips and placed on the internal side of a Varian Cary 50 UV-vis spectrophotometer cell (Agilent Technologies, Santa Clara, CA, USA), perpendicularly to the light beam. The absorbance spectrum $(400-800 \mathrm{~nm})$ of the film samples was recorded, and opacity was defined as the area under the recorded curve (estimated by the linear trapezoidal rule) and expressed as absorbance units $\times$ wavelength in nanometers/film thickness in millimeters (A $\mathrm{nm} \mathrm{mm} \mathrm{m}^{-1}$ ). Fourier-transform infrared spectroscopy (FTIR) spectra were recorded in the Cary 660 FTIR spectrophotometer (Agilent Technologies, Santa Clara, CA, USA), in the wavenumber range from 4,000 to $650 \mathrm{~cm}^{-1}$ with a resolution of $4 \mathrm{~cm}^{-1}$ over 128 scans. Scanning electronic microscopy (SEM) images were taken using the DSM 940A microscope (Carl Zeiss AG, Oberkochen, Germany); the samples were mounted on an aluminum stub using doublesided adhesive carbon tape, coated with platinum, and examined with an accelerating voltage of $15 \mathrm{kV}$ and a magnification of 1,000 times.

The MSG per gelatin ratio that resulted in the film with the best combination of tensile and barrier properties was then used to produce the bionanocomposite films. The films were prepared by adding different concentrations of CNCs -2.5 , 5.0 , and $7.5 \%$ on a dry MSG + gelatin basis - to the MSG/gelatin dispersion. This was done as previously described for films with different MSG per gelatin ratios until glycerol addition. The $\mathrm{CNC}$ suspension was then added, and the film forming dispersion was subjected to sonication in a 400-W ultrasonic processor (UP400S, Hielscher Ultrasonics, Teltow, Germany) with a titanium $\mathrm{H} 22$ sonotrode, working at a $24 \mathrm{kHz}$ for $10 \mathrm{~min}$. The dispersions were vacuum degassed, and the procedure was carried out as described for films with different MSG per gelatin ratios.

Pesq. agropec. bras., Brasília, v.53, n.4, p.495-503, Apr. 2018 DOI: 10.1590/S0100-204X2018000400011 
Analyses of variance and Tukey tests were carried out using Minitab 15 (Minitab Inc., State College, PA, USA), in order to study the effects of both the MSG per gelatin ratio on the film tensile and barrier properties, and of the different $\mathrm{CNC}$ contents on the bionanocomposite films.

\section{Results and Discussion}

All regressions for the properties of MSG/gelatin films with different MSG per gelatin ratios were significant (Table 1). Increasing MSG per gelatin ratios resulted in improved tensile strength and modulus (Figure 1). The highest strength and modulus values were achieved from pure MSG films. However, increasing MSG per gelatin ratios sharply decreased elongation, probably due to the strong interactions between mannan chains in MSG, resulting in a densely packed structure with increased rigidity and brittleness (Mikkonen et al., 2007).

In the present study, the overall tensile properties of the composite films were roughly proportional to the MSG per gelatin ratios instead of being better than those of the films with either matrix alone; therefore, it is supposed that MSG and gelatin did not interact significantly with each other by intermolecular interactions such as crosslinks between the matrices (Siqueira et al., 2015), which is evidenced by FTIR (Figure 2). It should be noted that the fact that the composite films did not exhibit poorer tensile properties than the films from pure matrices is an indicative that there was no significant aggregation or phase separation between matrices, although the MSG/ gelatin film had a relatively rough surface compared with that of pure MSG or gelatin film (Figure 3).

Increasing MSG per gelatin ratio resulted in increased WVP, implying that gelatin was more effective than MSG in lowering WVP, due to the high content of hydrophobic amino acids in fish gelatin
(Benbettaïeb et al., 2016). Similarly, the addition of the galactomannan locust bean gum to whey protein films also resulted in films with higher WVP (Silva et al., 2016).

Therefore, while MSG was more effective than fish gelatin in producing stronger and stiffer films, gelatin contributed more in improving film ductility and lowering WVP (Figure 1 and Table 1). The best MSG/ gelatin ratio was defined as being 1:1, which resulted in a minimum WVP while keeping tensile strength at not less than $4 \mathrm{MPa}$, which is considered the lowest acceptable strength for food packaging materials (Tajeddin et al., 2010).

The CNCs had $3.8 \pm 0.7 \mathrm{~nm}$ in diameter and $319 \pm 23 \mathrm{~nm}$ in length. The zeta potential of the CNCs was measured as $-30 \mathrm{mV}$, which is an indicative that the CNCs were adequately dispersible in water (El Miri et al., 2015), also facilitating their dispersion in hydrophilic matrices such as MSG/gelatin.

The tensile strength and modulus of the bionanocomposite films were improved by the presence of the CNCs (Figure 4), although CNC concentrations higher than $2.5 \mathrm{wt} \%$ did not further affect the elastic modulus. The improvements, mainly in strength, occurred despite the irregular surfaces of the films observed through SEM (Figure 3), suggesting some $\mathrm{CNC}$ aggregation even at $2.5 \mathrm{wt} \%$. The tensile strength was highest - about 35\% higher than that of the control film - at $5 \mathrm{wt} \%$ CNCs. The elongation at break, however, was noticeably decreased by the addition of CNCs, being reduced to less than $50 \%$ at $5 \mathrm{wt} \% \mathrm{CNCs}$, when compared with the film without $\mathrm{CNCs}$, which may be due to the rigidity of the CNCs, as well as to the interactions between CNCs and to the reduction in the plasticizing effect of glycerol. Other studies have also found improvements in strength and modulus of protein and/or polysaccharide films by CNCs, while elongation was impaired (Pereda et al.,

Table 1. Estimated regression coefficients for properties of films with different mesquite seed gum per gelatin (MSG:gelatin) ratios in pseudo-components.

\begin{tabular}{|c|c|c|c|c|c|c|}
\hline \multirow[t]{2}{*}{ Response } & \multicolumn{3}{|c|}{ Terms } & \multirow[t]{2}{*}{ F-value } & \multirow[t]{2}{*}{$\mathrm{p}$-value } & \multirow{2}{*}{$\begin{array}{l}\mathrm{R}^{2} \\
(\%)\end{array}$} \\
\hline & MSG & Gelatin & MSG:gelatin & & & \\
\hline Tensile strength $(\sigma)$ & 7.60 & 1.36 & -1.74 & 23.06 & 0.042 & 95.84 \\
\hline Elongation at break $(\varepsilon)$ & 8.40 & 86.94 & -2.35 & 20.37 & 0.047 & 95.32 \\
\hline Elastic modulus (E) & 3.43 & 0.28 & -3.53 & 22.21 & 0.043 & 95.69 \\
\hline Water vapor permeability (WVP) & 1.35 & 0.97 & 0.30 & 100.15 & 0.010 & 99.01 \\
\hline
\end{tabular}

Pesq. agropec. bras., Brasília, v.53, n.4, p.495-503, Apr. 2018

DOI: $10.1590 / \mathrm{S} 0100-204 X 2018000400011$ 
2014; Santos et al., 2014; Pereira et al., 2017) because of the stiffness of the material due to the percolating network of CNCs (Anglès \& Dufresne, 2001). The highest $\mathrm{CNC}$ content $(7.5 \mathrm{wt} \%)$ caused not only a further decrease in elongation, but also a decrease in strength, which was probably due to CNC aggregation, as previously reported for high CNC contents (Pereda et al., 2014).

The WVP of films was decreased by CNCs (Figure 4), corroborating previous studies (Pereda et al., 2014; Santos et al., 2014). The best barrier to water vapor was observed with $5 \mathrm{wt} \% \mathrm{CNCs}$, showing $23 \%$ less permeability than the control film; however, WVP
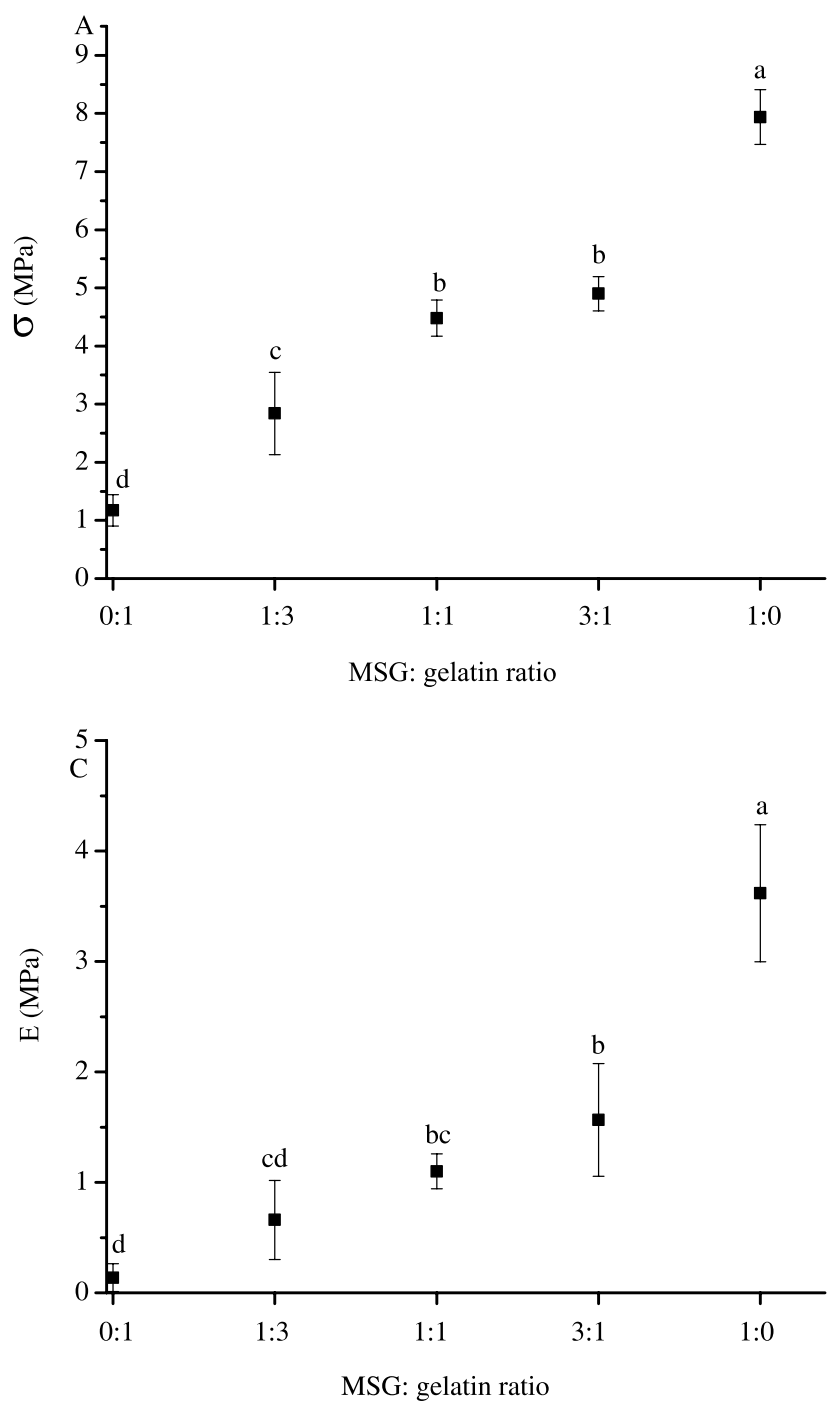

increased at $7.5 \mathrm{wt} \%$, which is also attributed to $\mathrm{CNC}$ aggregation, producing channels that allowed water vapor to permeate (Santos et al., 2014).

One drawback of adding CNCs to the films was the increased opacity (Figure 2) caused by the CNCs filling the voids between polymer chains, which created hurdles for light to pass through the films. This result is in alignment with the effects of $\mathrm{CNC}$ on films as reported in a previous study (Pereira et al., 2014).

The FTIR spectra (Figure 2) shows bands ascribed to the presence of water, such as the one around $3,310 \mathrm{~cm}^{-1}$ for the axial deformation of hydroxyl groups (Abugoch
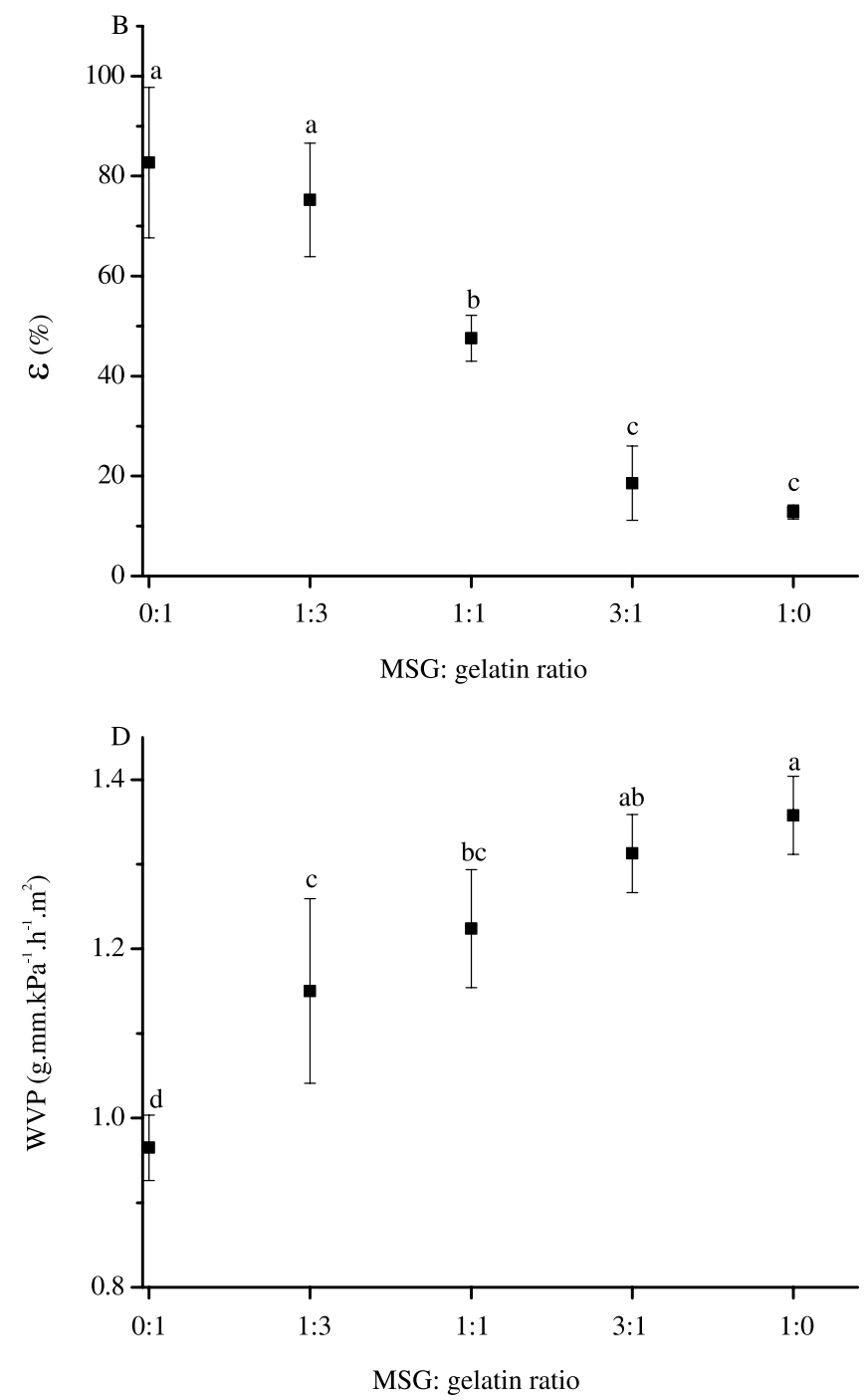

Figure 1. Properties of films with different mesquite seed gum per gelatin (MSG:gelatin) ratios: A, tensile strength $(\sigma)$; B,

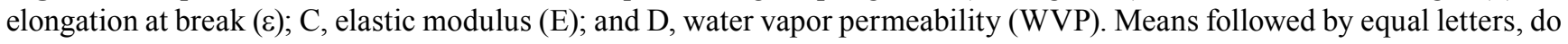
not differ by Tukey's test, at 5\% probability. 


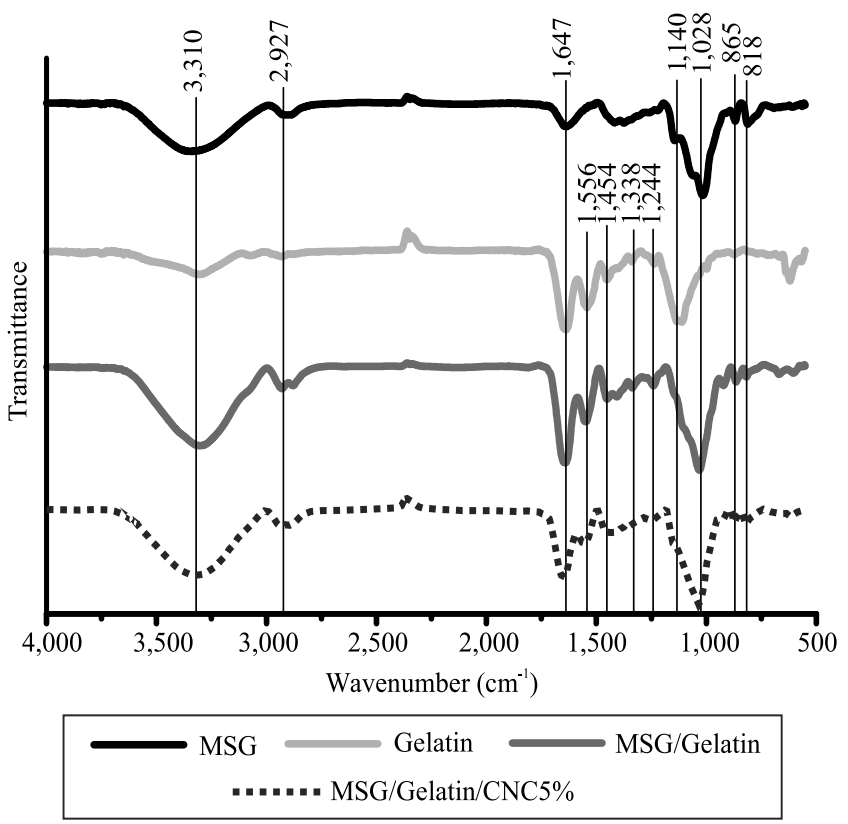

Figure 2. Fourier-transform infrared spectroscopy (FTIR) spectra of films from mesquite seed gum (MSG), gelatin, 1:1 MSG/gelatin composite (MSG/Gelatin), and MSG/ gelatin composite with $5 \mathrm{wt} \%$ cellulose nanocrystals (MSG/ Gelatin $/ 5 \%$ CNCs). et al., 2011) and the one around $1,650 \mathrm{~cm}^{-1}$ for $\mathrm{H}-\mathrm{O}-\mathrm{H}$ bending of absorbed water (Szymanska-Chargot \& Zdunek, 2013), although the latter has been overlapped with C-N stretching from amide I when gelatin was present (Szymanska-Chargot \& Zdunek, 2013). The band at $2,927 \mathrm{~cm}^{-1}$ is ascribed to $\mathrm{C}-\mathrm{H}$ stretching of the methyl and methylene groups of polymers (Valenzuela et al., 2013), which was less noticeable when gelatin was the only matrix. Bands typical of galactomannans are those at 869 and $814 \mathrm{~cm}^{-1}$, ascribed to the anomeric configurations ( $\alpha$ and $\beta$ ) of galactose and mannose, respectively (Kačuráková et al., 2000). Bands ascribed to gelatin were those for amide II at $1,340-1,560 \mathrm{~cm}^{-1}$ and for amide III at 1,244 $\mathrm{cm}^{-1}$ (Kuan et al., 2016). The band at $1,028 \mathrm{~cm}^{-1}$ is ascribed to $\mathrm{C}-\mathrm{O} / \mathrm{C}-\mathrm{C}$ stretching (Elizondo et al., 2009; Szymanska-Chargot \& Zdunek, 2013), being less noticeable when gelatin was the only matrix; this band shifted to higher wavenumbers in the presence of gelatin, suggesting interactions between gelatin and the polysaccharides MSG and CNCs. The band at $1,140 \mathrm{~cm}^{-1}$, ascribed to $\mathrm{C}-\mathrm{O}$ stretching at glycosidic bonds (Elizondo et al., 2009; Liu et al., 2016),
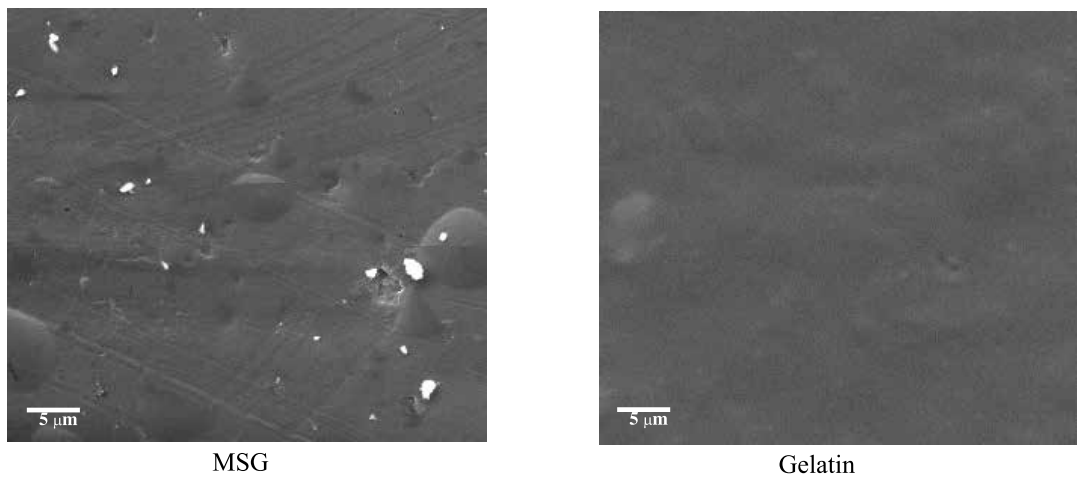

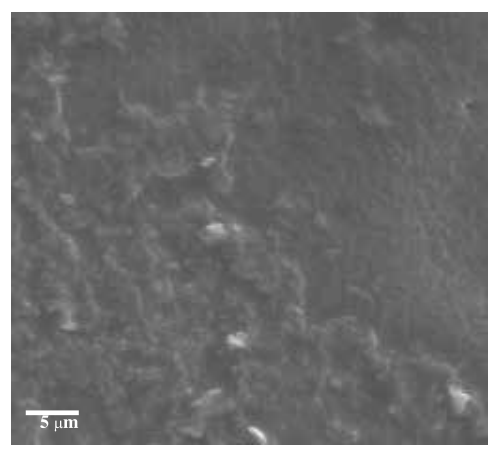

MSG/Gelatin

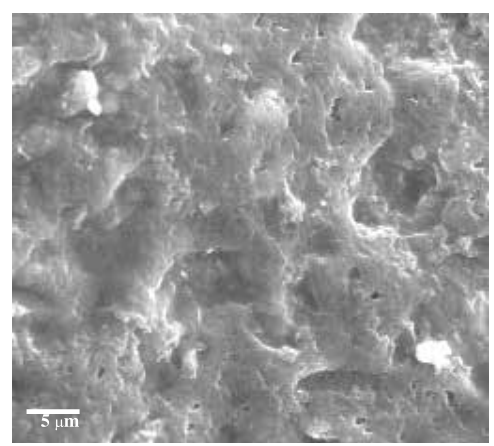

$\mathrm{MSG} / \mathrm{Gelatin}+2.5 \% \mathrm{CNCs}$

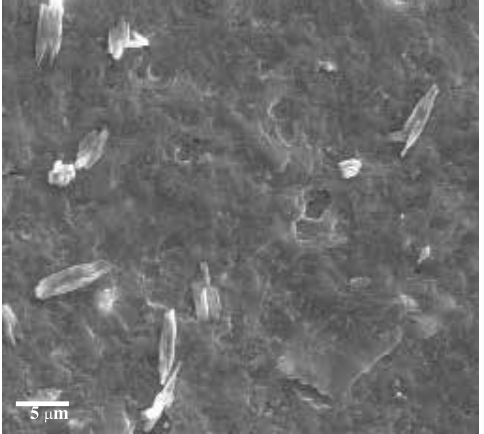

$\mathrm{MSG} /$ Gelatin $+5 \% \mathrm{CNCs}$

Figure 3. Scanning electron micrographs of the evaluated films from mesquite seed gum (MSG), gelatin, 1:1 MSG/gelatin composite, MSG/gelatin composite $+2.5 \%$ cellulose nanocrystals (CNCs), and MSG/gelatin composite $+5 \%$ CNCs. 

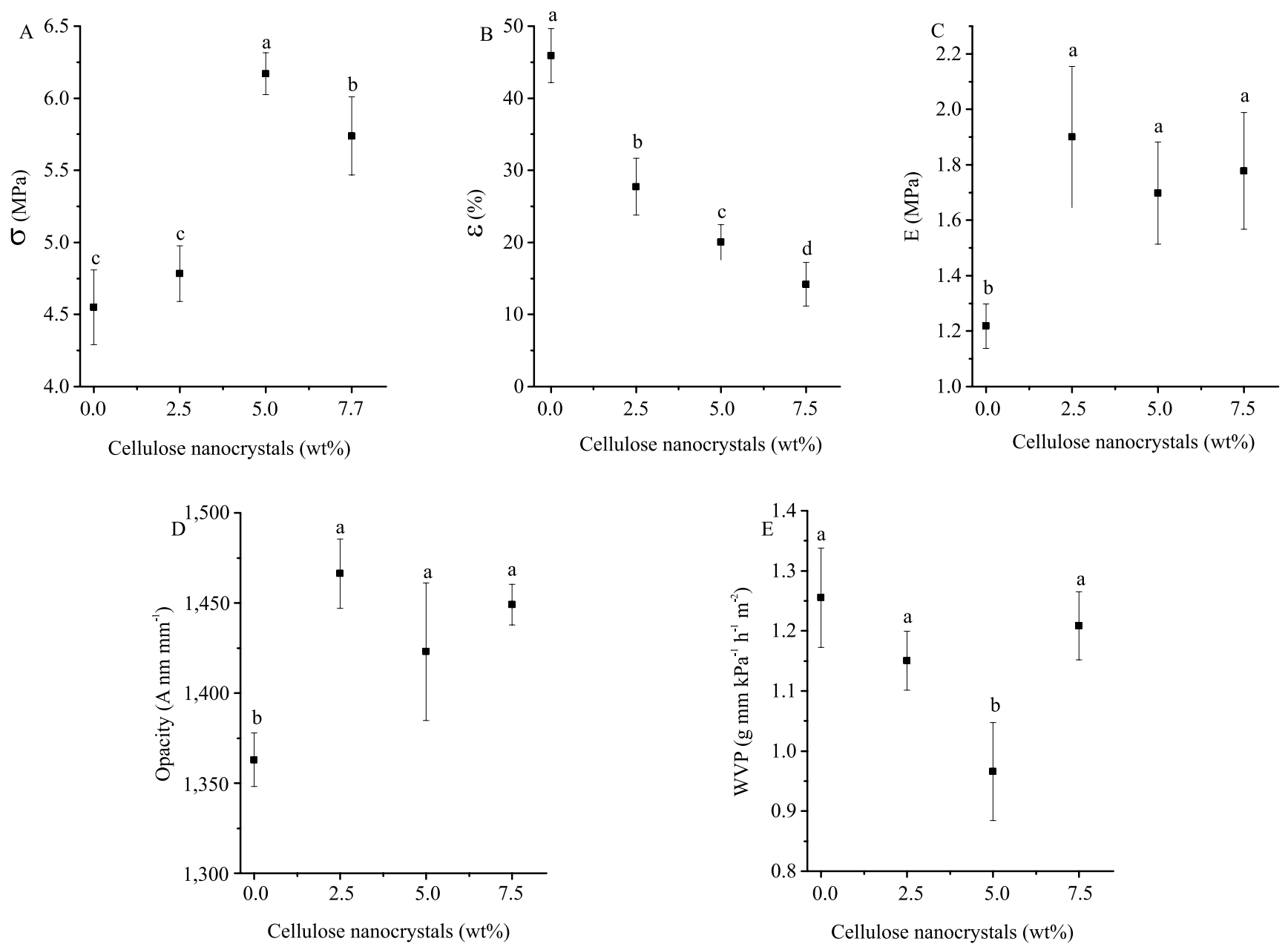

Figure 4. Properties of mesquite seed gum per gelatin composite films with different cellulose nanocrystal contents: A, tensile strength $(\sigma)$; B, elongation at break $(\varepsilon)$; C, elastic modulus (E); D, opacity; and E, water vapor permeability (WVP). Means followed by equal letters, do not differ by Tukey's test, at $5 \%$ probability.

was more intense in films containing gelatin, which is probably associated with the glycation of collagen (Muyonga et al., 2004); the band shifted to higher wavenumbers when MSG was added, indicating the occurrence of hydrogen bonds between the matrices. By the spectra, there were no significant interactions between film components, such as covalent crosslinks or noncovalent interactions, confirming the lack of improvement in tensile properties when gelatin and MSG were mixed to form films.

\section{Conclusions}

1. The best mesquite seed gum (MSG) per gelatin weight ratio to produce films of low water vapor permeability and good overall tensile properties is 1:1.
2. MSG/gelatin films have their tensile and barrier properties improved by the presence of $5 \mathrm{wt} \%$ cellulose nanocrystals (CNCs).

3. CNC contents higher than $5 \mathrm{wt} \%$ impair both tensile and water vapor barrier properties.

\section{Acknowledgments}

To Empresa Brasileira de Pesquisa Agropecuária (Embrapa), for financial support (projects 02.11.01.003.00.00 and Agronano Network); and to Conselho Nacional de Desenvolvimento Cientifico e Tecnológico (CNPq), for the productivity fellowships awarded to the third and fifth authors (project numbers 305504/2016-9 and 302381/2016-3, respectively). 


\section{References}

ABDOLLAHI, M.; ALBOOFETILEH, M.; BEHROOZ, R.; REZAEI, M.; MIRAKI, R. Reducing water sensitivity of alginate bio-nanocomposite film using cellulose nanoparticles. International Journal of Biological Macromolecules, v.54, p.166-173, 2013. DOI: 10.1016/j.ijbiomac.2012.12.016.

ABUGOCH, L.; TAPIA, C.; VILLAMÁN, M.C.; YAZDANIPEDRAM, M.; DÍAZ-DOSQUE, M. Characterization of quinoa protein-chitosan blend edible films. Food Hydrocolloids, v.25, p.879-886, 2011. DOI: 10.1016/j.foodhyd.2010.08.008.

ANGLÈS, M.N.; DUFRESNE, A. Plasticized starch/tunicin whiskers nanocomposite materials. 2. Mechanical behavior. Macromolecules, v.34, p.2921-2931, 2001. DOI: 10.1021/ ma001555h.

ASTM. American Society for Testing and Materials. ASTM D882-10: standard test method for tensile properties of thin plastic sheeting. West Conshohocken: American Society for Testing and Materials, 2010a.

ASTM. American Society for Testing and Materials. ASTM E96-10: standard test method for water vapor transmission of materials. West Conshohocken: American Society for Testing and Materials, 2010b.

BENBETTAÏEB, N.; KARBOWIAK, T.; BRACHAIS, C.H.; DEBEAUFORT, F. Impact of electron beam irradiation on fish gelatin film properties. Food Chemistry, v.195, p.11-18, 2016. DOI: 10.1016/j.foodchem.2015.03.034.

BRAS, J.; VIET, D.; BRUZZESE, C.; DUFRESNE, A. Correlation between stiffness of sheets prepared from cellulose whiskers and nanoparticles dimensions. Carbohydrate Polymers, v.84, p.211215, 2011. DOI: 10.1016/j.carbpol.2010.11.022.

CHIOU, B.-S.; AVENA-BUSTILLOS, R.J.; BECHTEL, P.J.; IMAM, S.H.; GLENN, G.M.; ORTS, W.J. Effects of drying temperature on barrier and mechanical properties of cold-water fish gelatin films. Journal of Food Engineering, v.95, p.327-331, 2009. DOI: 10.1016/j.jfoodeng.2009.05.011.

EL MIRI, E.; ABDELOUAHDI, K.; ZAHOUILY, M.; FIHRI, A.; BARAKAT, A.; SOLHY, A.; EL ACHABY, M. Bionanocomposite films based on cellulose nanocrystals filled polyvinyl alcohol/chitosan polymer blend. Journal of Applied Polymer Science, v.132, 2015. DOI: 10.1002/app.42004.

ELIZONDO, N.J.; SOBRAL, P.J.A.; MENEGALLI, F.C. Development of films based on blends of Amaranthus cruentus flour and poly(vinyl alcohol). Carbohydrate Polymers, v.75, p.592-598, 2009. DOI: 10.1016/j.carbpol.2008.08.020.

FONTES, A.; NIKOLIK, G.; RASMUSSEN, IKEDA, V. Feeding nemo: turning Brazil's economic turmoil into seafood business opportunities. 2016. Available at: <http://seafoodbrasil.com.br/ wp-content/uploads/2016/08/Rabobank_IN564_Feeding_Nemo_ Fontes_August2016.pdf>. Accessed on: Feb. 32017.

GUERRERO, P.; GARRIDO, T.; LECETA, I.; DE LA CABA, K. Films based on proteins and polysaccharides: preparation and physical-chemical characterization. European Polymer Journal, v.49, p.3713-3721, 2013. DOI: 10.1016/j.eurpolymj.2013.08.014.
HORCAS， I.; FERNÁNDEZ， R.; GÓMEZ-RODRÍGUEZ, J.M.; COLCHERO, J.; GÓMEZ-HERRERO, J.; BARO, A.M. WXSM: a software for scanning probe microscopy and a tool for nanotechnology. Review of Scientific Instruments, v.78, 2007. DOI: $10.1063 / 1.2432410$.

IRISSIN-MANGATA，J.; BAUDUIN， G.; BOUTEVIN, B.; GONTARD, N. New plasticizers for wheat gluten films. European Polymer Journal, v.37, p.1533-1541, 2001. DOI: 10.1016/S00143057(01)00039-8.

KAC̆ URÁKOVÁ, M.; CAPEK, P.; SASINKOVÁ, V.; WELLNER, N.; EBRINGEROVÁ, A. FT-IR study of plant cell wall model compounds: pectic polysaccharides and hemicelluloses. Carbohydrate Polymers, v.43, p.195-203, 2000. DOI: 10.1016/ S0144-8617(00)00151-X.

KUAN, Y.-H.; NAFCHI, A.M.; HUDA, N.; ARIFFIN, F.; KARIM, A.A. Effects of sugars on the gelation kinetics and texture of duck feet gelatin. Food Hydrocolloids, v.58, p.267-275, 2016. DOI: 10.1016/j.foodhyd.2016.02.025.

LEUANGSUKRERK, M.; PHUPOKSAKUL, T.; TANANUWONG, K.; BOROMPICHAICHARTKUL, C.; JANJARASSKUL, T. Properties of konjac glucomannan-whey protein isolate blend films. LWT - Food Science and Technology, v.59, p.94-100, 2014. DOI: 10.1016/j.lwt.2014.05.029.

LI, C.; ZHU, W.; XUE, H.; CHEN, Z.; CHEN, Y.; WANG, X. Physical and structural properties of peanut protein isolategum Arabic films prepared by various glycation time. Food Hydrocolloids, v.43, p.322-328, 2015. DOI: 10.1016/j. foodhyd.2014.06.003.

LIU, X.; ZHANG, N.; YU, L.; ZHOU, S.; SHANKS, R.; ZHENG, J. Imaging the phase of starch-gelatin blends by confocal Raman microscopy. Food Hydrocolloids, v.60, p.7-10, 2016. DOI: 10.1016/j.foodhyd.2016.03.005.

MIKKONEN, K.S.; RITA, H.; HELÉN, H.; TALJA, R.A.; HYVÖNEN, L.; TENKANEN, M. Effect of polysaccharide structure on mechanical and thermal properties of galactomannanbased films. Biomacromolecules, v.8, p.3198-3205, 2007. DOI: $10.1021 / \mathrm{bm} 700538 \mathrm{c}$.

MORAIS, J.P.S.; ROSA, M. de F.; SOUZA FILHO, M. de S.M. de; NASCIMENTO, L.D.; NASCIMENTO, D.M. do; CASSALES, A.R. Extraction and characterization of nanocellulose structures from raw cotton linter. Carbohydrate Polymers, v.91, p.229-235, 2013. DOI: 10.1016/j.carbpol.2012.08.010.

MUYONGA, J.H.; COLE, C.G.B.; DUODU, K.G. Fourier transform infrared (FTIR) spectroscopic study of acid soluble collagen and gelatin from skins and bones of young and adult Nile perch (Lates niloticus). Food Chemistry, v.86, p.325-332, 2004. DOI: 10.1016/j.foodchem.2003.09.038.

PEREDA, M.; DUFRESNE, A.; ARANGUREN, M.I.; MARCOVICH, N.E. Polyelectrolyte films based on chitosan/olive oil and reinforced with cellulose nanocrystals. Carbohydrate Polymers, v.101, p.1018-1026, 2014. DOI: 10.1016/j. carbpol.2013.10.046.

PEREIRA, A.L.S.; NASCIMENTO, D.M. do; SOUZA FILHO, M. de S.M. de; MORAIS, J.P.S.; VASCONCELOS, N.F.; FEITOSA, J.P. de A.; BRÍGIDA, A.I.S.; ROSA, M.F. Improvement of 
polyvinyl alcohol properties by adding nanocrystalline cellulose isolated from banana pseudostems. Carbohydrate Polymers, v.112, p.165-172, 2014. DOI: 10.1016/j.carbpol.2014.05.090.

PEREIRA, P.H.F.; WALDRON, K.W.; WILSON, D.R.; CUNHA, A.P.; BRITO, E.S. de; RODRIGUES, T.H.S.; ROSA, M. de F.; AZEREDO, H.M.C. de. Wheat straw hemicelluloses added with cellulose nanocrystals and citric acid. Effect on film physical properties. Carbohydrate Polymers, v.164, p.317-324, 2017. DOI: 10.1016/j.carbpol.2017.02.019.

SANTOS, T.M.; SOUZA FILHO, M. de S.M. de; CACERES, C.A.; ROSA, M. de F.; MORAIS, J.P.S.; PINTO, A.M.B.; AZEREDO, H.M.C. de. Fish gelatin films as affected by cellulose whiskers and sonication. Food Hydrocolloids, v.41, p.113-118, 2014. DOI: 10.1016/j.foodhyd.2014.04.001.

SILVA, K.S.; MAURO, M.A.; GONÇALVES, M.P.; ROCHA, C.M.R. Synergistic interactions of locust bean gum with whey proteins: effect on physicochemical and microstructural properties of whey protein-based films. Food Hydrocolloids, v.54, p.179188, 2016. DOI: 10.1016/j.foodhyd.2015.09.028.

SIQUEIRA, G.; ABDILLAHI, H.; BRAS, J.; DUFRESNE, A. High reinforcing capability cellulose nanocrystals extracted from Syngonanthus nitens (Capim Dourado). Cellulose, v.17, p.289298, 2010. DOI: 10.1007/s10570-009-9384-z.
SIQUEIRA, N.M.; PAIVA, B.; CAMASSOLA, M.; ROSENTHAL-KIM, E.Q.; GARCIA, K.C.; SANTOS, F.P. dos; SOARES, R.M.D. Gelatin and galactomannan-based scaffolds: characterization and potential for tissue engineering applications. Carbohydrate Polymers, v.133, p.8-18, 2015. DOI: 10.1016/j. carbpol.2015.06.039.

SZYMANSKA-CHARGOT, M.; ZDUNEK, A. Use of FT-IR spectra and PCA to the bulk characterization of cell wall residues of fruits and vegetables along a fraction process. Food Biophysics, v.8, p.29-42, 2013. DOI: 10.1007/s11483-012-9279-7.

TAJEDDIN, B.; RAHMAN, R.A.; ABDULAH, L.C. The effect of polyethylene glycol on the characteristics of kenaf cellulose/ low-density polyethylene biocomposites. International Journal of Biological Macromolecules, v.47, p.292-297, 2010. DOI: 10.1016/j.ijbiomac.2010.04.004.

VALENZUELA, C.; ABUGOCH, L.; TAPIA, C. Quinoa proteinchitosan-sunflower oil edible film: mechanical, barrier and structural properties. LWT - Food Science and Technology, v.50, p.531-537, 2013. DOI: 10.1016/j.lwt.2012.08.010.

VIEIRA, Í.G.P.; MENDES, F.N.P.; GALLÃO, M.I.; BRITO, E.S. de. NMR study of galactomannans from the seeds of mesquite tree (Prosopis juliflora (Sw) DC). Food Chemistry, v.101, p.7073, 2007. DOI: 10.1016/j.foodchem.2005.11.052.

Received on February 3, 2017 and accepted on July 10, 2017

Pesq. agropec. bras., Brasília, v.53, n.4, p.495-503, Apr. 2018 DOI: 10.1590/S0100-204X2018000400011 